\title{
THE METASTATIC THEORY OF PATHOGENESIS AND THE PROFESSIONAL INTERESTS OF THE EIGHTEENTH-CENTURY PHYSICIAN
}

\author{
by
}

\section{MALCOLM NICOLSON*}

In two papers published during the mid-1970s, N. D. Jewson proposed a sociological explanation for the character of eighteenth-century medical knowledge. ${ }^{1} \mathrm{He}$ argued that medical knowledge was then produced by a particular form of social interaction between patients and their physicians, who competed for customers in an open and pluralistic market-place. This competition was not controlled by rigorous academic or professional criteria. Economic authority rested wholly with the customer-the patient. Jewson argued that the patient's power of patronage structured the social dynamics of the consultative encounter, with the patient playing a much more active part than in the nineteenth or twentieth centuries. Physicans had to exert themselves, in primary social interaction with their patients, to gain and retain employment. If the patient was not convinced or impressed by one practitioner, he could summon another. It was thus necessary for the physician to provide the patient with acceptable rationales for his diagnostic pronouncements and proposed therapeutic procedures. Likewise, the patient's subjective experience of his disorder constituted the primary reality on which the understanding of disease was based. ${ }^{2}$ The most favoured therapeutic agents and procedures generally had effects directly perceivable by the patient.

Jewson's stimulating but largely theoretical analysis has only recently begun to receive the attention it deserves. Historians of medicine are assembling materials that allow the accuracy of the model to be assessed. ${ }^{3}$ The three major premises on which Jewson based his argument-shared vocabulary, easy lay access to alternative forms of

*Malcolm Nicolson, PhD, Wellcome Institute for the History of Medicine, 183 Euston Road, London NW1 2BP.

${ }^{1}$ N. D. Jewson, 'Medical knowledge and the patronage system in eighteenth-century England', Sociology, 1974, 8: 369-385; idem, 'The disappearance of the sick man from medical cosmology 1770-1870', ibid, 1976, 10: 225-240.

2 For the dependence of diagnosis on the patient's testimony, see S. J. Reiser, Medicine and the reign of technology, Cambridge University Press, 1978, pp. 1-22; and C. Newman 'Diagnostic investigation before Laennec', Med. Hist., 1960, 4: 322-9. I have discussed this aspect of the Jewson thesis and eighteenth-century patient-practitioner interaction in my 'Giovanni Morgagni and eighteenth-century physical diagnosis', in C. Lawrence (editor), Medical theory and surgical practice, London, Croom Helm, [forthcoming].

${ }^{3}$ R. Porter, 'Lay medical knowledge in the eighteenth century: the evidence of the Gentleman's Magazine', Med. Hist., 1985, 29: 138-168; idem., 'Laymen, doctors and medical knowledge in the eighteenth century: the evidence of the Gentleman's Magazine', in idem., (editor), Patients and practitioners: lay perceptions of medicine in pre-industrial society, Cambridge University Press, 1985, pp. 283-314; Joan Lane, " The doctor scolds me": the diaries and correspondence of patients in eighteenth-century England', in ibid., pp. 205-248; Virginia Smith, 'Prescribing the rules of health: self-help and advice in the late eighteenth century', in ibid., pp. 249-282; C. Rosenberg, 'Medical text and medical context: explaining William Buchan's Domestic 
health care, and the exercise of economic authority by the patient-have all received some empirical substantiation. We are now in a good position to exploit the heuristic value of Jewson's work. The present paper is intended to be a contribution to the task of developing and refining the insights into eighteenth-century medical knowledge that Jewson offers.

One of the important consequences Jewson drew from his model was that eighteenth-century medical knowledge was not the unique preserve of the medical profession. Medical discourse was, on the contrary, in the public domain. The active participation of the patient in diagnosis and therapy sustained a common vocabulary of health and disease, shared between laymen and professionals. Jewson also proposed that the eighteenth-century physician employed a variety of devices in his attempt to attract paying customers. He displayed theoretical and therapeutic innovation; he flourished medical and classical erudition; he developed a fashionable and selfadvertising life-style; and he presented the patient with convincing and attractive rationales for diagnosis and therapy. Yet, in stressing the practitioner's need to accommodate himself to the economic power of the patient, Jewson did not complete the inventory of the professional tactics available to the eighteenth-century physician. He failed to consider whether the information conveyed by physician to customer contained not only the positive attractions listed above, but also negative sanctionssticks as well as carrots-, threats of dire consequences should the patient disregard the prerogatives of physic and take his custom elsewhere. In particular, I shall examine how technical ideas about the causation of disease and its spread within the body were employed to aid the physician in the furtherance of his professional interests. The common vocabulary of health and disease gave physicians a resource with which they could attempt to exercise control over customers and prospective customers. ${ }^{4}$

The essay will also indicate how Jewson's thesis may be extended both geographically and chronologically. Jewson applied his model only to England. However, it seems likely that the economic and social context of élite practice was, to some extent, similar throughout many parts of Western Europe. ${ }^{5}$ I have accordingly

medicine', Bull. Hist. Med., 1983, 57: 22-42. Not all these authors explicitly relate their work to that of Jewson, but the information they provide is very pertinent to the assessment of his thesis.

${ }^{4}$ Other studies of the use of medical knowledge for purposes of social control lead us to suspect that negative sanctions against disapproved behaviour are likely to be employed. See, for example, C. Smith-Rosenberg and C. E. Rosenberg, 'The female animal: medical and biological views of woman and her role in nineteenth-century America', J. Amer. Hist., 1973, 60: 332-356; C. E. Rosenberg, 'Florence Nightingale on contagion: the hospital as moral universe', in idem., (editor) Healing and history: essays for George Rosen, New York, Dawson, 1976, pp. 116-136; A. Comfort, The anxiety-makers, London, Nelson, 1967.

${ }^{5}$ For the socio-economic context of various forms of medical practice in Paris, see T. Gelfand, 'Medical professionals and charlatans; the Comité de Salubrité enquête of 1790-91', Histoire Sociale-Social History, 1978, 11: 62-97, and idem., Professionalizing modern medicine: Paris surgeons and medical science and institutions in the eighteenth century, Westport, Conn., Greenwood Press, 1980. For Edinburgh, see A. Cunningham, 'The medical professions and the pattern of medical care: the case of Edinburgh, circa 1670 -circa 1700', in W. Eckart and J. Geyer-Kordesch (editors), Heilberufe und Kranke im 17. und 18. Jahrhundert die Quellen- und Forschungssituation, Munster, Burgverlag, 1982, pp. 9-28; and R. M. Stott, 'The incorporation of surgeons and medical education and practice in Edinburgh, 1696-1755', PhD thesis, University of Edinburgh 1984. For Germany, see J. Geyer-Kordesch, 'Medical biographies of the eighteenth century: reflections on medical practice and medical education in Germany', in Eckart and Geyer-Kordesch, 


\section{The metastatic theory of pathogenesis}

drawn examples from Dutch and Italian sources as well as English ones. This evidence seems to support the suggestion that the physicians of these countries faced the same problems as their English counterparts in preserving their reputations, building their practices, and defending themselves against competition. Conclusions along these lines must as yet be very tentative. However, the Jewson thesis seems prima facie to be of too great heuristic value for its application to be restricted to a single country. Furthermore, the emphasis Jewson places on medical knowledge usefully encourages an international perspective on eighteenth-century medicine. It is easy, in the light of the many excellent local studies now available, to underestimate the extent to which eighteenth-century physic was genuinely an international culture, united by a common language and by a body of shared knowledge. These links were sustained by much movement of personnel, both students and teachers, by the trade in books and medical artefacts, and by a vast amount of personal correspondence. The expression of this international body of knowledge was, of course, extensively modulated according to local or national requirements. But national medical culture never had a wholly independent life of its own.

Nor should the Jewson thesis be confined to an arbitrarily circumscribed time period. Although Jewson restricted his remarks to the eighteenth century, some of my central examples are taken from the consultation letters of John Symcotts, who practised physic in Bedford in the middle of the seventeenth century. ${ }^{6}$ The similarity between his medical discourse and that of the eighteenth-century authors I quote from will be evident. Historians sometimes talk of eighteenth-century medicine as if it were sui generis, a thing entirely of itself. ${ }^{7}$ Jewson's emphasis on social and economic structure ought to provide a valuable corrective here. The eighteenth century saw a bewildering proliferation of medical texts and theories - that seems indeed to have been a distinctive feature. However, Jewson gives us grounds to suspect that much of this new theorizing was produced by a fashion for arbitrary novelty. The details of each new theory may therefore be of no great cultural significance. Fascinating as such superficial variation might be for the intellectual historian, it should not be allowed to prevent the recognition of much more stable and enduring patterns of professional interest and patient-practitioner interaction. It is also clear that the economic structure

op. cit., pp. 124-127. For Spain, see M. Burke, The Royal College of San Carlos: surgery and Spanish medical reform in the late eighteenth century, Durham, North Carolina, Duke University Press, 1977.

${ }^{6}$ Symcotts'sextant correspondence, casebooks, and case histories have been printed in F. N. L. Poynterand W. J. Bishop (editors), A seventeenth-century doctor and his patients: John Symcotts, 1592?-1662, Streatly, Bedfordshire Historical Record Society, vol. 31. The editors' introduction, pp. vii-xxxiv, collates all the available biographical material. John Symcotts is also discussed in L. M. Beier, 'Sufferers and healers: health choices in seventeenth-century England', $\mathrm{PhD}$ thesis, University of Lancaster, 1984.

Jewson based his analysis on the activities of élite physicians, whose clients were the rich and powerful. Symcotts, a provincial physician, cannot be regarded as having been at the top of his profession. Nor were many of his patients above the middling order of society. Yet social and economic constraints seem to have structured his interaction with his patients in a way very similar to that outlined by Jewson. Jonathan Barry points out that the apothecaries and the medicine-sellers of eighteenth-century Bristol were often equally at the mercy of their customers, J. Barry, 'Piety and the patient: medicine and religion in eighteenth-century Bristol', in Porter (editor), op. cit., note 3 above, pp. 145-176. It seems that the Jewson thesis may offer some insight into the social constraints experienced by all strata of eighteenth-century medical practitioners.

${ }^{9}$ Even as sensitive a commentator as $\mathbf{R}$. Porter has appeared, no doubt in an unguarded moment, to endorse this view, Porter, 'Lay medical knowledge', op. cit., note 3 above, p. 164. 


\section{Nicolson}

of eighteenth-century medical practice was inherited without radical alteration from the seventeenth century. ${ }^{8}$ Furthermore, economic interests were pursued in the same manner in the early nineteenth century - at least by those medical practitioners socially or geographically distant from the birth of the clinic and the movement towards more formal professionalization. ${ }^{9}$ Jewson's analysis ought to apply wherever medical knowledge was diffused throughout the public domain and wherever seventeenth-, eighteenth-, and early nineteenth-century physicians had actively to persuade patients, by direct social interaction, to submit to their authority, to accept their diagnoses and their forms of therapy, in preference to a large array of alternatives. $^{10}$

Although the medical theory of the eighteenth century was extremely complex, some generally prevailing sets of assumptions can be cautiously identified. Most physicians would have accepted, at least in outline, the following account of the causation of disease. ${ }^{11}$ Morbid, or potentially morbid, material was present in the body even in health. However, the healthy body was capable of rendering such material harmless and expelling it. This was one function of the normal processes of excretion. However, if the normal channels of expulsion were overwhelmed or the internal organs weakened, morbid material could accumulate in the body and cause ill health. If it was long confined, this matter might change its character, perhaps becoming more acrid and injurious. In sickness, the body would labour to discharge morbid matter either by increasing normal discharges, hence diarrhoea or the profuse sweating of fever, or by making abnormal exits, such as the discharging pustules of smallpox. The aim of medical intervention was to facilitate this process of expulsion. ${ }^{12}$

\footnotetext{
${ }^{8}$ Note that my argument here is not that there was nothing new in the eighteenth-century medicine or its social context. It is the economic and social constraints upon the physicians' interaction with their customers, as described by Jewson, which are postulated, for the purposes of empirical investigation, to have been essentially constant from the seventeenth century to, in some cases, the early nineteenth. There would, of course, be enormous geographical and chronological variation, both in the force with which these constraints applied and in how physicians responded to the challenges they posed. If it is accepted that the socio-economic framework of practice was similar in the seventeenth century to that described by Jewson for the eighteenth, then we may utilize seventeenth-century material to support the Jewson thesis. Of particular interest in this regard are L. M. Beier, 'In sickness and in health: a seventeenth-century family's experience', in Porter (editor), op. cit., note 3 above, pp. 101-128; and idem., op. cit., note 6 above.

${ }^{9}$ Jewson (1976), op. cit., note 1 above, argues that the rise of hospital medicine brought about a change in the dominant mode of production of medical knowledge that led to the demise of eighteenth-century medical knowledge. A similar point is argued by M. Foucault, The birth of the clinic: an archaeology of medical perception, London, Tavistock, 1973. See also D. Armstrong, Political anatomy of the body, Cambridge University Press, 1983, esp. ch. 1.

${ }^{10}$ It is interesting to note that the author whose interpretation of medical knowledge has come closest to Jewson's is Charles Rosenberg, describing not eighteenth- but early nineteenth-century medicine, and not in England, but in America. See C. Rosenberg, 'The therapeutic revolution: medicine, meaning and social change in nineteenth-century America', Persp. Biol. Med., 1977, 20: 485-506. A somewhat different version of this paper was published in M. J. Vogel and C. E. Rosenberg (editors), The therapeutic revolution: essays in the social history of medicine, Philadelphia, University of Pennsylvania Press, 1979, pp. 3-25.

${ }^{11}$ See, for example, the description of "a common framework of concepts and terms" in A. Cunningham, 'Sydenham versus Newton: the Edinburgh fever dispute of the 1690 s between Andrew Brown and Archibald Pitcairne', in W. F. Bynum and V. Nutton (editors), Theories of fever from antiquity to the Enlightenment, London, Wellcome Institute for the History of Medicine, 1981, pp. 71-98.

${ }^{12}$ Intense as the debates between medical theorists were, it did not make much practical difference to the understanding of disease at the bedside whether the morbid matter was conceived of as particulate or humoral. Many theorists combined both forms of explanation. See note 82 below.
} 
As well as being expelled to the outside, morbid material could be transferred from site to site within the body, thus altering the locus of disease. This was what eighteenth-century writers referred to as metastasis. ${ }^{13}$ Such translation of material could turn a mild complaint into a dangerous one, if it was carried from a non-vital part to a vital organ. For instance, the drying-up of a cutaneous ulcer might cause serious disease if the morbid material formerly expelled through the skin accumulated within an internal organ. This idea of metastatic translation of disease is a virtually constant feature of eighteenth-century disease theory. ${ }^{14}$ Examples of its use abound. Here is one from Gerard Van Swieten's Commentaries on Boerhaave's aphorisms:

\begin{abstract}
A man aged thirty-four years was treated by his physician for the cure of a pleurisy; and with such success that the fever and the pain of his left side were so far reduced by the second day of the malady, that the patient thought himself almost entirely cured, and neglected to observe any further cure or regimen, but with an event that at last proved fatal to him; for he lived afterwards in a languishing condition, and confessed he always perceived an obtuse pain in the part that was first affected. Within a few weeks after his first illness he had a considerable swelling in his right leg, that again disappeared of itself; and another of the like sort shewed itself after that in the right side, and of a considerable magnitude, that again spontaneously disappeared. Lastly, a like tumour appeared in the left thigh, and while it there continued another swelling formed itself upon the inner side of the right arm, becoming soft and larger than one's fist. At length succeeded a dysentery, an ascites and anasarca, with weakness, and death closed the scene .... This whole history informs us, that an inflammation of the spleen, being by the neglect of the patient not completely cured, degenerated into a suppuration; and that the matter thence absorbed was by various translations, or metastases, deposited upon divers other parts, until at length, the whole mass of blood was corrupted with a purulent cacochymia. ${ }^{15}$
\end{abstract}

Van Swieten substantiated this opinion with autopsy evidence. One of the noteworthy features of this case history is the intrinsic criticism of the patient. It is through the patient's neglect of proper physic that the fatal metastatic translation of his disease occurs. He ends up, therefore, in a much worse state than if he had diligently attended to the advice of his doctor. Here we see the suasive potential of the metastatic theory displayed. The major part of the present paper will be devoted to exploring how this aspect of disease theory was used to defend the hegemony of the physician over his professional rivals and so persuade the patient to submit himself to physic.

${ }^{13}$ See G. Van Swieten, Commentaries on Boerhaave's aphorisms, London, Horsfield, 1744-73, 18 vols., vol. 10, pp. 263-269. According to the OED, the use of the term "metastasis" to mean "the transference of morbific matter from one part or organ to another" dates from 1663. Symcotts referred to the same phenomenum under the heading 'De humorum translatione', (Poynter and Bishop (editors), op. cit., note 6 above, p. 52). See also J. R. Wilder 'The historical development of the concept of metastasis', J. Mt. Sinai Hosp., 1956, 23: 728-734; and S. Jarcho 'Some lost, obsolete, or discontinued diseases: serous apoplexy, incubus and retrocedent ailments', Trans. Stud. Coll. Physns. Phila., 1980, 2: 241-266.

${ }^{14}$ In principle, a strict adherent to an ontological theory of disease might have a logical problem in accepting the reality of the metastatic transformation of one disease to another. In fact, even Sydenham, frequently identified as a rigid ontologist, readily utilized the concept of metastasis, perhaps making a distinction between the essence of a disease and the effects of its expression within the body. See, for example, T. Sydenham, Medical observations, p. 151, in R. G. Latham (trans.) The works of Thomas Sydenham, M.D., London, The Sydenham Society, 1848, 2 vols., vol. 1, pp. 1-275. For Sydenham's ontology and the distinction between ontological and physiological theories of disease, see $\mathrm{O}$. Temkin, 'The scientific approach to disease; specific entity and individual sickness', in A. C. Crombie (editor), Scientific change: historical studies in the intellectual, social and technical conditions for scientific discovery, London, Heinemann, 1963, pp. 629-647.

${ }^{15}$ Van Swieten, op. cit., note 13 above, vol. 9, pp. 321-322. For biographical details of Van Swieten, see F. T. Brechka, Gerhard Van Swieten and his world, 1700-1772, The Hague, Nijhoff, 1970. 


\title{
M. Nicolson
}

As noted above, the major premises of Jewson's model have recently received important empirical substantiation. However, the relevant evidence has necessarily been gathered from relatively circumscribed areas. Therefore the pertinence of the Jewson thesis to any specific individual or social situation cannot yet be taken for granted. The first part of the paper will therefore be devoted to demonstrating that those physicians whose use of the metastatic theory I shall later examine were indeed constrained by customer agency and freedom of choice in the manner suggested by Jewson.

\section{SHARED KNOWLEDGE, PROBLEMATIC AUTHORITY}

Jewson argued that the eighteenth-century physician had to provide his patients with a convincing rationale for diagnosis and therapy. Here is an extract from a letter written by John Symcotts to one of his patients:

\begin{abstract}
The crick of your neck, the pain of your toe, the swelling of your knees and the trembling of your joints which you call the palsy are all from one and the same cause. The hotter temper of your liver is not only the fountain of the hot and sharp humour of choler surcharging the mass of blood, from whence comes that preternatural heat which you feel, but also that the serous watery humour (which dilutes the mass of blood and by his tenuity makes it apt to be carried from place to place) is unnaturally salt and sharp which, being an excrementitial part of the mass, is from the same separated and voided by urine, by sweat, or insensible transpiration. Now in case natural heat be languid and delayed (as in age it must be) it is lodged in some sensible part, as among the nerves, muscles and membranes, and there by his unkindly qualities causes exceeding anguish and pain. From hence comes sharp headache, the squincy, pleurisy, backache, the sciatica, joint sickness and the gout, of which kind your disease is, though it may have another name from the place where it is decumbent. The weakness of the stomach is from pain of other parts, which by sympathy affects the stomach; but I am so called upon by others this busy day that I cannot proceed in discourse. ${ }^{16}$
\end{abstract}

Symcotts was writing to a difficult patient who often consulted other practitioners, read popular medical texts, criticised Symcotts and administered remedies to himself. Symcotts, by going into considerable detail as to the underlying causes of the patient's ill health, was evidently attempting to persuade his customer of the correctness of his understanding of the complaint. When not "so called upon by others", he could go on to outline the purpose of therapy:

The course which I have propounded to myself in your cure is this; first, by a gentle purgative way to abate such serous and waterish humours which must necessarily abound in the first region by your sedentary life and so are the antecedent matter of those which (abounding in the liver, veins and other inward parts and likewise in the whole habit of the body) have had by long custom found an irregular vent for themselves by ways not destinated of nature to such a purpose, and therefore, though great and sudden evacuations may well evacuate the offensive cause yet can they never alter that habit which the law of custom shall impose and it must be disannulled by . . . degrees . . . ${ }^{17}$

Symcotts went on to give detailed advice on purging, bleeding, massage, exercise, diet, and life-style, all justified in detail according to his understanding of the patient's constitution. We can see the extent to which medical knowledge was transferred and shared between practitioner and patient.

\footnotetext{
${ }^{16}$ Symcotts to Powers, 15 July 1633, in Poynter and Bishop (editors), op. cit., note 6 above, pp. 25-26. For an account of consultation by letter, see G. Risse, 'Doctor William Cullen, physician, Edinburgh: a consultation practice in the eighteenth century', Bull. Hist. Med., 1974, 48: 330-351.

${ }_{17}$ Symcotts to Mistress Halford, undated, in Poynter and Bishop (editors), op. cit., note 6 above, pp. $15-16$.
} 


\section{The metastatic theory of pathogenesis}

The activity of the patient within the consultative interaction is further evidenced by the fact that the patient could dispute the physician's diagnosis, as Van Swieten documented in the following case: "He would not permit the surgeon to search him with the sound, asserting that this had been attempted in vain some years before, by an able lithotomist in Italy, who introduced a finger into the anus, felt a great hardness, whence he concluded that the bladder was schirrhous; which the patient also believed, being angry if $I$ but hinted the least suspicion of a stone in the bladder." 18

Alternatively, the patient could accept the diagnosis but not submit to the form of treatment that the physician proposed. Even while under the physician's direction, the patient might be able considerably to affect the form of therapy he received. He might, for instance, successfully demand a particular remedy against the better judgement of his doctor: "The patient had heard, from Michelotti, that the urine of a heifer had succeeded with him, more than once, in the case of an anasarca. As he was, therefore, desirous of trying, though neither the time of the year, nor some other circumstances of the kind, were such as L'Emery would have prefer'd, yet I indulg'd him .... I indulg'd him, however, with this restriction, that he should not drink more than seven ounces on the first day, and should add two ounces every day afterwards." 19

Here the physician, Giovanni Morgagni, was relegated to regulating dosages and monitoring the patient's progress. Even as eminent and authoritative a physician as Morgagni, Professor of Medicine and Anatomy at the University of Padua, and very much an élite practitioner, ${ }^{20}$ seems routinely to have had difficulty getting patients to adhere strictly to his precepts. Indeed, he considered it worthy of a remark when a patient had "not disdained to take my advice, though a young man". 21

Likewise, patients might dispute that a treatment had been effective or that a cure had taken place. Van Swieten gave several examples of patients refusing to believe that they had been cured of the pox because they had not been salivated-a reference to the popular belief that the profuse salivation produced by mercury carried the virus of pox out of the body. 22

The capacity for lay dissent could express itself in the medical market-place, for the physican's medical knowledge was not the only form of expertise available to the sick person. He also had access to popular texts, to surgeons and apothecaries. He could go to folk-healers and irregular practitioners of various sorts. Advice would be received from family and friends. Self-treatment was always an option. The layman had direct access to drugs, quite independent of supervision by any form of practitioner. The following case was given by Van Swieten:

\footnotetext{
18 Van Swieten, op. cit., note 13 above, vol. 16, pp. 240-241. Note that here the physician has to depend upon the patient's account of the diagnostic event.

${ }^{19}$ G. B. Morgagni, The seats and causes of diseases, investigated by anatomy, trans. B. Alexander, London, A. Miller \& T. Cadell, 1796, 3 vols., vol. 2, p. 305.

${ }^{20}$ For biographical details of Morgagni, see S. Jarcho, 'Giovanni Battista Morgagni; his interests, ideas and achievement', Bull. Hist. Med., 1948, 22: 503-524. See also idem (editor), The clinical consultations of Giambattista Morgagni: the edition of Enrico Benassi, Boston, Countway Library of Medicine, 1984, esp. editor's preface.

${ }^{21}$ Morgagni, op. cit., note 19 above, vol. 1, p. 733.

22 Van Swieten, op. cit., note 13 above, vol. 17, p. 308.
} 


\section{Nicolson}

I had a young man under cure, who was not ignorant of the medical art. I gave him some doses of white precipitate and the first signs of an approaching salivation readily appeared. I was desirous, as usual, to desist from the further application of mercury, until I first saw the progress of the salivation. The patient being dissatisfied and impatient with this delay, sent to an apothecary for five grains of Turbith-mineral unknown to me; and immediately swallowed that dose, with a design, as he said, either to cure or kill himself .... I was, in three hours after, hastily called to succour the wretch, then at death's door. ${ }^{23}$

The physician's authority was therefore chronically problematic. This was true not only at the level of individual interaction between doctor and patient but also at the level of the local community as a whole. Morgagni provided many examples of how readily the medical practitioner was prey to hostile gossip and adverse criticism: "As most persons of the city, where this nobleman resided, inveigh'd against the physician and surgeon, according to custom, as having injudiciously, and without reason, taken blood away on that day, and hereby brought on the immediate death of their noble patient ...."24

It is clear, therefore, that Jewson's description of the problems of eighteenthcentury practice is borne out by the experiences of the physicians whose work I examine in this paper. All are faced with chronic problems of authority, of suasion and social control. To develop and maintain his practice, the physician must actively persuade his patients to accept his advice rather than that of their medical books, their friends, or some form of rival medical practitioner. Meanwhile, he must preserve his personal reputation at all costs.

\section{THE SUASIVE USAGE OF THE METASTATIC THEORY}

Eighteenth-century physicians responded energetically to such challenges. The economic power of the patient did not reduce them to passivity or fawning servility. They could play the system as actively as their customers could. The medical knowledge which they shared with their patients constituted a valuable resource that could be utilised in the enhancement of their authority and in the defence of their utility. In the account of disastrous self-administration, quoted above, we see an example of what seems to have been a routine professional tactic. Van Swieten's implicit argument was that if the physician's supervision is foregone, if his advice is ignored, dire consequences will follow for the patient. The metastatic theory lent itself admirably to the transmission of the same message. Here is Symcotts again, writing to one of his patients who wished to follow lay advice and have blistering agents applied: "Whatever your neighbours ignorantly talk against physic your own judgement can inform you that for the easing of so principal a part, the voiding of the humours of blisters had been improper, and remedies applied for mitigation might easily repel that viscious humour unto the noble parts, with which course many curing an outward pain, kill themselves". ${ }^{25}$ Symcotts defended the good name of physic with the ultimate sanction - the threat of capital punishment. Only after the state of the humours had been rectified by regimen and physic, and the internal

${ }^{23}$ Ibid., vol. 16, p. 352.

${ }^{24}$ Morgagni, op. cit., note 19 above, vol. 1, p. 456. My italics.

${ }^{25}$ Symcotts to Powers, 1 June 1633, in Poynter and Bishop (editors), op. cit., note 6 above, pp. 20-21. 
organs had been restored to health and strength, might "Outward remedies ... safely be applied and you shall see with a little time and patience all will do well". ${ }^{26}$

In a similar manner, Symcotts used the metastatic theory to interpose his expertise between the patients and a rival source of medical knowledge, the popular medical book. One of his patients possessed a copy of William Vaughan's Naturall and artificial directions for health. ${ }^{27}$ The patient seems to have quoted to Symcotts Vaughan's recommendation for the application of excoriating plasters in cases of sore joints. Symcotts replied: "You see how the case stands; your pain of your knees is from an inward fountain; if by plasters you break this swelling before sharp humours be voided otherwise, that part may unhappily gangrenate; if not, yet I think it a very improper way to void humours by a solid part, where there is no patent way to convey humours by, whereas they may be carried speedily and safely by the common drain of nature's, by gentle purges. I have therefore prescribed you a regular course which, if you follow, I make no question by your author Vaughan his prognostic vain and frivolous". ${ }^{28}$

Symcotts was also able to employ the metastatic theory to argue against alternative forms of therapy proposed by professional rivals. On one occasion, an itinerant practitioner visited the neighbourhood, and one of Symcott's regular customers, $\mathrm{Mr}$ Powers, went to consult him. The recommendations he received differed from those previously given by Symcotts. The next time he was consulted by Powers, Symcotts felt it necessary to exert himself to defend the correctness and rationality of his procedures and regain the confidence of his client. Again, Symcotts stressed the dangers of moving the humours about indiscriminately, and the greater safety of the skilled and cautious application of physic by a qualified physician: "For your doctor his advice, I like it not; such rowelling, drawing and slabbering smells too much of his barber's shop from whence he went out $\mathrm{Dr}$. These are remedies never to be used till the whole body be well rectified, not by a mad evacuation of the humours, but by a restitution of the temper; otherwise such means will soon cause a greater confluxion of humours and a consecution thereof." 29

Surgeons could likewise be over-eager and jealous in the exercise of their craft. Here we must remember that, in the seventeenth and eighteenth centuries, the surgeon's domain was, officially at any rate, the external surface of the body. His special expertise lay in dealing with wounds, ulcers, fistulas, gangrenes, and so on. The physician, on the other hand, claimed the whole body as his province. His skill was held to be the intellectual one of understanding the workings of the internal constitution. Thus physicians promoted their form of expertise as superior to and more comprehensive than that of the surgeon. To emphasize this, they argued that the surgeon's routine procedures for healing ulcers and sores were full of danger unless due attention was given to the internal state of the body, which only the physician could determine. Moist or running ulcers released morbid matter which, if denied this outlet, could accumulate within the body causing internal disease. In other words, surgical intervention required the supervision of a physician. Symcotts provided another of his patients with the

26 Ibid., p.21.

${ }^{27} \mathrm{~W}$. Vaughan, Naturall and artificial directions for health, London, Bradocke, 1600.

${ }^{28}$ Symcotts to Powers, undated, in Poynter and Bishop, (editors), op. cit., note 6 above, p. 26.

${ }^{29}$ Symcotts to Powers, 13 December 1636, in ibid., p. 28. 


\section{Nicolson}

following cautionary tale about the consequences of resorting to purely surgical remedies: "Sir Thomas Nevil of Holt, having had an issue in his leg which ran much, he would needs have it healed by a surgeon about Michaelmas 1635. About Christmas following he found his stomach ill and all parts out of order .... After, he fell into asthmatical fits, was hectical, grew weaker, his urine utterly confused, and so continued for 11 or 12 days .... At last ... he fell into a great quivering and within 7 hours after died. The only cure had been the opening his issue in time." 30

Physicians did not deny that surgeons possessed specialized and useful skills, skills which were often an essential component of adequate therapy. However, as part of their maintenance of professional hegemony, they claimed the right to control and direct the surgeon's activities. The dangers of the translation of disease legitimated this claim. Meanwhile, of course, the patient had to pay two sets of fees, for surgeon and physician. He must not be tempted, for fear of the worst, to try to economize and hire only a surgeon. The metastatic theory, therefore, was used by the physician to protect the boundaries of his special area of expertise and economic interest. ${ }^{31}$

As well as healing ulcers, seventeenth- and eighteenth-century surgeons also created ulcers and issues artificially in order to allow the release of morbid humours. This form of surgical treatment was also, Symcotts argued, often inadequate unless supplemented by internal remedies. Effective as issues often were, Symcotts cautioned against "too much confidence in issues alone without due purgatives". ${ }^{32}$ If administered correctly by a physician who understood his patient's constitution and the internal state of the humours, purgatives would loosen morbid matter and aid its release, both through the issue and along the normal channels: "Colonel Herby of Thurleigh, trusting to his issue in his arm (made at London) neglected the taking such usual course of physic (as his rheumatic and nephritic case required) this last fall of the leaf, and thereby a tumour arose under his armhole, induced much pain ...".33 The unfortunate Colonel Herby, no doubt, was persuaded to pay two sets of fees next autumn.

The metastatic theory therefore provided Symcotts with a resource he could employ in arguing against self-treatment, against popular medical books, empirics or itinerants, and against surgeons acting independently-against, in fact, all his main professional rivals, since in Bedford he did his own dispensing and so had no apothecary to quarrel with. ${ }^{34}$ The metastatic theory conveniently rendered the physician indispensable to all other ranks of the medical hierarchy and displayed the essential relevance of his distinctive skills.

We find the same professional utilization of the metastatic theory in the writings of Morgagni. As noted above, Morgagni was rather a different sort of practitioner from Symcotts. He was a very eminent physician indeed. However, Morgagni was not above

\footnotetext{
${ }^{30}$ Symcotts's casebook, in ibid., p. 52.

31 Note that there is nothing in this account of physicians' use of the metastatic theory that prohibits surgeons from using the same or similar notions for their own purposes. Indeed, it seems likely that certain aspects of the Jewson model could be usefully applied to several strata of the eighteenth-century medical profession. See note 67 below and note 6 above.

32 Ibid., p. 81.

33 Ibid., p. 82.

34 Ibid., p. xxvi.
} 


\section{The metastatic theory of pathogenesis}

the struggle. He shared Symcotts's concern to establish the indispensability of the physician and to maintain hegemony over the inferior strata of the healing professions. Morgagni was especially skilled in post-mortem examinations. He was, therefore, in an excellent position to pronounced on the shortcomings of inadequate forms of therapy-for he could point directly to their fatal results. Such pointing had a direct pedagogic relevance. Morgagni was a very important teacher, being one of the most senior professors at one of the major medical schools of Europe. Most of his dissections were done in public before an audience of students and junior colleagues. His published accounts of his clinical and post-mortem investigations served an explicitly pedagogic function. ${ }^{35}$ We can see from Morgagni's textbooks that providing students with resources for the defence of physic was an integral part of élite orthodox pedagogy. Morgagni provided his audience with many useful exemplifications of the distinction between good and bad medical practice.

The following case history from Morgagni's most famous text, De sedibus, is typical. A woman had a fever with many alarming symptoms. She seemed to be recovering with treatment but suddenly she died. Dissecting the body, Morgagni deduced that the treatment for the fever had been discontinued before the causative material was completely expelled from the body: "But if we consider all the circumstances attentively, there were other things which might have warn'd the physician, whoever he was, not to trust that remission of the disorder; but, even, on the contrary, to be the more suspicious of danger .... Doubtless, that deprav'd matter, which, being dispersed through the body, had, by its irritation, given occasion to the general disorder, was collected into one part, and that the most excellent, the brain". ${ }^{36}$ The metastatic theory here sustained a distinction between good practitioners, such as Morgagni, and poor ones, such as that of the fever patient. Good physicians, by the knowledge of theory and by clinical acumen, would have discerned that the patient was still being affected by depraved matter. By way of contrast, Morgagni gave an account of a similar case in which a skilled physician recognized that "the common disease of the whole body was subdued but not that disease of a particular part". ${ }^{37}$ Treatment was administered to release a local concentration of morbid matter and the patient made a full recovery. Note that, in a situation where physicians were competing one with another, an ability to cast aspersion on the skill of other physicians might have been very important in maintaining a competitive advantage. Equally, it would be tactical to emphasize the efficacy of forms of practice similar to one's own.

We see the same range of usages of the metastatic theory in Morgagni as in Symcotts. Not only did Morgagni employ the metastatic theory to distinguish good and bad practice, he also used it to warn of the danger of administering remedies without professional supervision: "A nobleman ... left the joints very weak. And in order to strengthen these parts, having us'd to great excess the baths that are near Verona and the mud of those baths, without any advice but his own rash determination, he was not at all the better but even soon after began to be troubled with pains of the heart ... with

\footnotetext{
35 Morgagni, op. cit., note 19 above, vol. 1, pp. xix-xx.

36 Ibid., p. 69.

37 Ibid., vol. 2, p. 203.
} 


\title{
M. Nicolson
}

inflammations of the eyes, and haemorrhages at the nose." 38 The man's condition deteriorated, his pains got worse, convulsions set in, and he died. In autopsy, Morgagni exposed the cause of his frightful symptoms and his eventual demise:

\begin{abstract}
For when the body was dissected ... in the falciform process of the dura mater were found five bones of different forms and magnitudes; but almost all of them horrid, as it were, with sharp spines ... from the time the patient had abus'd the mud of the baths, above mention'd, and studied to dispel from the joints the matter which had been accustomed to cause a gout, some part of this matter was intercepted betwixt the fibres of the falciform process, and begun to bring on pains of the head, to which he had never before been subject: and that the same matter gradually concreting afterwards into these bones which have been describ'd had excited those convulsions, after they had begun, with their sharp points, to prick both the meninges . . . 39
\end{abstract}

Self-treatment is thus demonstrated to have painful and fatal consequences.

Again like Symcotts, Morgagni also employed theories of disease causation in such a way as to render the surgeon's expertise subordinate to that of the physician. Surgery is safe only if supervised by the physician:

A rustic of the territory of Bologna ... had for a long time past had filthy ulcers in his legs which he eagerly desir'd should be heal'd. Therefore, although he was of a bad habit of body, for the most part, nor went to stool for six days, without taking purging medicines or having glysters thrown up: yet having got a very officious surgeon, he brought the matter so far to a conclusion, that after three months, the ulcers being cleans'd, began to heal. The cicatrix was not completed, when he began suddenly to complain of a very great weakness in his head; . . . on the third day, he first began to be delirious, and presently to lose the sense of feeling in his whole body . . . at length, being depriv'd of all power of feeling and moving . . . he died. ${ }^{40}$

Dissection confirmed the existence of "deprav'd matter" between the pia mater and the brain. The moral of this case history was that, to put it bluntly, the excessive zeal of the surgeon killed the patient. A physician skilled in attending to the internal condition of the body would have realised that the leg ulcers were necessary for the removal of excremental matter from the body because the functioning of the normal channels was impaired, as evidenced by the patient's chronic constipation. Deprived of even abnormal exits, the excremental material could not be released and formed fatal deposits within the internal organs.

Treatment by empirics and unorthodox practitioners was equally unsound and dangerous: "A woman about thirty years of age was seiz'd with a great and moist scabies, after long continu'd pains of the limbs. In order to drive this away, she, by the advice of an empiric, made use of a certain ointment. And by this means, her scabies was dried up in a very short time indeed: but an acute fever arose, attended with a great heat and thirst, and very severe pains of the head. To these symptoms were afterwards added a delirium, a considerable difficulty of breathing, a slight tumour of the whole body, but not a slight one of the belly, great uneasiness, and, finally death . . .,41 Morgagni gave the following explanation for the unfortunate case: "The very great

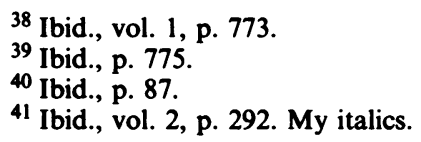


and humid scabies, which had freed this woman from long-continued pains in her limbs, being improperly repell'd, brought on death. That is to say, the acrid particles which had been accustom'd, before, to prick and vellicate the membranes of the limbs, were now salubriously thrown out, by means of little ulcers produc'd on the skin. But when these ulcers dried up, these particles, of course, remain'd in the blood and irritated the internal parts; and this brought on the acute fever, and the other very violent disorders which accompanied it ..." 42 Here again a skilled physician could have, Morgagni implied, brought this case to a better conclusion-for, as he said, "all physicians know the dangers of precipitously drying up scabies". ${ }^{43}$

Morgagni knew of the existence of "animalcules"-itch-mites- and acknowledged that they were frequently associated with the lesions of scabies. ${ }^{44} \mathrm{He}$ accepted that the transfer of animalcules from person to person was the reason why scabies was often very contagious. However, he did not accept that scabies was wholly an external, contagious disorder: "Nor can we easily assent, when it be said, that a scabies never arises but from the contact of a scabious person, or from his animalculae. Does it never rise from nastiness? Never from improper eating and drinking? It certainly seems otherwise to most physicians. " 45 To Morgagni, scabies was not solely a disease of the skin. Its ulcers were often the outward sign of the presence of "deprav'd matter" within the body. ${ }^{46} \mathrm{He}$ cited observations of the blood and urine of scabious patients which evidenced this, the urine on occasion being "black and fuliginous", the blood sometimes "viscid and condens'd". ${ }^{47}$ Therefore: ". . . how could it be safe to apply a cure to the skin promiscuously in all persons and neglect the internal parts?"48

The social significance of these arguments is that scabies, not being wholly an external condition, fell therefore within the professional borderlines of physic. The physician need not concede its treatment to other practitioners. The section which argues these points is one of the longest in De sedibus. It may be relevant here that scabies was one of the few conditions for which an undoubtedly effective remedy, namely sulphur, was available to barber-surgeons, empirics, and the laity. Therefore Morgagni was obliged to argue against it and to assert the necessity of physic. Morgagni did not deny the power of sulphur to heal scabious ulcers. However, he questions the safety of the treatment in lay hands, emphasising the difference between physicians' practice and lay practice in the administration of sulphur: "... [sulphur] is us'd, in one way by the physicians, and in another way by the common-people ... now hear the manner in which the common-people make use of sulphur against the scabies, and what inconveniences and injuries sometimes happen therefrom ... . I knew a young woman, who, having taken some in this manner, soon after felt so great a disturbance in her head, that she seemed then to herself to be almost mad." 49 Another woman died of fever, convulsions and intestinal disorders after dosing herself with

\footnotetext{
42 Ibid.

${ }^{43}$ Ibid.

44 Ibid., vol. 3, pp. 242-247.

45 Ibid., p. 244.

46 Ibid., p. 249.

47 Ibid.

48 Ibid., p. 250.

49 Ibid.
} 


\title{
M. Nicolson
}

sulphur for scabies. ${ }^{50}$ Her husband died in the same way. ${ }^{51}$ The moral is clear: "You see, then, of how much importance it is not to drive back a disorder of this kind: and that they do not talk altogether idly, who deny that a scabies is always a disease of the skin alone, and consequently that remedies are to be applied to the skin alone; neglecting the cure of the remaining part of the body: and not only if this be neglected; but attempted in such a manner as to distort the motion of nature, when verging to the skin; sometimes death, and at other times various disorders, are the consequence." 52

As always, Morgagni was able to appeal to what is to him the final arbiter of medical truth-post-mortem dissection-for support for his views on scabies. With his access to corpses and his skill in dissection, he could display, within the body, the effects of disease. Sometimes, he could even point to the "depraved matter", repulsed from the skin, lodging within some vital organ:

\begin{abstract}
... I would have you observe, that, in consequence of these little ulcers being dried up ... by any kind of unctions whatever, an infant perish'd by convulsions; a virgin, by a dropsy of the thorax and pericardium; a woman, by an acute fever and tympanites; and a young man, by a suppression of urine: and that the causes of death had arisen from the occlusion of the little ulcers; for, as when open and discharging they kept off diseases ... so when dried up, they retain'd in the blood those stimulating particles, and noxious humours, which were before eliminated and discharg'd thereby; and which were soon afterwards effus'd, in almost all of them, either betwixt the meninges, and into the belly, or into the thorax, which I found to be full of blueish water in the virgin whom I have mention'd. 53
\end{abstract}

Morgagni cited many eminent physicians who agreed with him on the necessity of internal treatment for scabies. ${ }^{54}$ The usage of metastatic theory I have described for Morgagni was, evidently, quite general throughout the eighteenth century. Van Swieten, for example, articulated a rationale for medical intervention based firmly on the metastatic theory of disease causation and propagation: "In a child of three months old there arose an abscess about the right shoulder; but as the parents would not allow it to be opened, the tumour naturally subsided of itself, but the absorbed matter being translated to the genital parts, it there produced a fatal gangrene. There are many observations of the like nature, which demonstrate how dangerous it is to leave concocted matter confined for too long a time in a vomica or abscess". 55

Here we have an example of a physician arguing for the necessity of surgical intervention. This should not, however, be interpreted as contradicting what has been said earlier about the competitive relationship between physicians and surgeons. While physicians did compete with surgeons for overall control of patients, they were also, in many cases, dependent on the special skills of the surgeon. The physician, therefore, must defend the validity of surgical intervention against the claims either of non-intervention or intervention by empirics, folk-practitioners, and others of that sort. Another example follows:

${ }^{50}$ Ibid., pp. 251-253.

51 Ibid., pp. 253-254. Morgagni decided that both these cases were caused by sulphur poisoning compounded by the accumulation of "deprav'd matter" within the internal organs.

${ }^{52}$ Ibid., p. 248.

53 Ibid., p. 240.

54 Ibid., pp. 242-249.

55 Van Swieten, op. cit., note 13 above, vol. 3, p. 430. My italics. 
Women in childbed often commit the cure of their inflamed breasts to their nurses, or to some doting old woman; and as they fear nothing more than a suppuration, and an opening of the suppurated part by the surgeon's lancet, they therefore use all their endeavours to prevent it ... they, by a dangerous error, expose the inflamed breast to the heat of a burning coal, or else continually foment it with very dry and hot linen cloths, or else they apply spirit of wine almost scalding, by which means, instead of a suppuration following, the more fluid parts are exhaled, and the rest of the matter is inspissated into an irresolvable schirrus; and then the unhappy woman who was so much afraid of a slight puncture with a sharp lancet, is frequently obliged afterwards to undergo the very severe and dangerous operation of amputating. ${ }^{36}$

Here it is not the repulsion of morbid particles from an external site to the internal organs that results in adverse consequences but the failure correctly to disperse an internal accumulation of material. However, the implication is the same. Failure to manage correctly the expulsion of morbid matter from within the body will have serious consequences. A skilled physician would first soften and loosen the inflammatory matter, bring on a suppuration, and thereby allow the matter to be completely discharged. Bad therapy, or even good therapy applied at the wrong time, would disperse and expel only the lighter elements within the inflammatory matter, leaving the remainder more strongly concreted and adhered. The inflammation might degenerate into a schirrus, or, eventually, a cancer. ${ }^{57}$

The special skills of the physician were required to decide not only on the form of treatment but also on the precise timing and frequency of its application. Symcotts, for example, refused to give a patient instructions as to how to self-administer a treatment to prevent facial scarring after smallpox: “. . . lest by the unseasonable use of them you might incur more danger from the disease itself". ${ }^{58}$ Symcotts adduced the following cautionary tale: "One Mr Sandys of Queens' College (a man of incomparable feature) advised to bathe his face (when the pox were dry) with new buttermilk well warmed, he, impatient of delay, used it a little too soon and repelled some part of the matter to his brain, which Mr Butler with all his skill could not help; he died for it." 59

John Rutherford, in his clinical lectures at Edinburgh, argued in a very similar manner. He did not deny that quacks and empirics often had effective remedies at their disposal: "To say in truth, all quacks remedies as far as I have examined them would cure the disease they are designed for if applied at the proper time and stage." ${ }^{60}$ It is this capacity to understand the temporal development of disease which was to Rutherford "the chief difference between a real physician and the empiric": ". . . there are so many circumstances that happen in every disease that it is difficult to find the exact time of applying this or that remedy .... Everyone may bleed, sweat, and vomit his patient but it is no everyone that knows when these are properly to be applied." ${ }^{.1}$ Like the physician mentioned above, Rutherford allied the metastatic theory of pathogenesis to considerations of distinguishing between good and bad practice. ${ }^{62}$

${ }^{56}$ Ibid., pp. 374-375.

57 Ibid., pp. 282-384. See also ibid., vol. 4, pp. 226-327.

58 Symcotts to William Symcotts, 10 June 1656, Poynter and Bishop (editors), op. cit., note 6 above, p. 5.

59 Ibid.

60 John Rutherford, 'Clinical lectures', student's manuscript notes, Edinburgh University Library, Dc. 10.28 , p. 7 .

${ }^{61}$ Ibid.

${ }^{62}$ Ibid., pp. 26-32. 


\section{Nicolson}

To the eighteenth-century physician, restitution of health was a temporal process, modulated by the changing conditions of the internal organs - changes which only he had sufficient skill to discern. This idea of time was at the heart of the metastatic theory and was an important aspect of how the theory legitimated physic against other forms of therapy. Morbid particles or humours might be safely moved at one time, not at another. Timing was, for example, the basis of Morgagni's objection to the common people's treatment of scabies. Sulphur, as he said, "is at one time to be commended, and at another disapproved". 63

The emphasis placed on timing by the physician mirrors the economic characteristics of his form of practice. The physician expected to supervise his patient's recovery over a long period of time, extracting a number of fees accordingly. ${ }^{64}$ Morgagni's internal therapy for scabies, for example, took many months. He recalled that, in one case: "I endeavour'd to obviate these symptoms speedily and diligently. But if nature had not assisted us ... we should certainly never have seen these pains critically solv'd within a month; nor the skin perfectly healed within the next spring ...."65 The physician might hope to be engaged for consultation even when the patient was not ill. He regarded his province as including not only the restoration of health but also its maintenance. A long and intimate acquaintance with one's physician was represented as being a sensible investment of time and money for the patient because the physician would thereby become acquainted with the normal variation of one's constitution and would thus develop greater acuity in identifying and understanding abnormal, pathological changes. ${ }^{66}$ The physician, therefore, exercised a continued form of care. He invested time not only in particular patients but in his geographical location. He built up a profitable practice gradually as he gained a clientèle and established himself a reputation by word of mouth within the community. ${ }^{67}$ Therapy was not confined to the time span of ordinary commercial transactions as it might be for a travelling empiric or a seller of nostrums. The metastatic theory sustained the physician's view of the duration of therapy, legitimating prolonged application of physic, slow and cautious moving of the humours. The metastatic theory thus made time work for the economic advantage of the physician. ${ }^{68}$

${ }^{63}$ Morgagni, op. cit., note 19 above, vol. 3, p. 250.

${ }^{64}$ See L. King, The medical world of the eighteenth century, University of Chicago Press, 1958, ch. 1. Symcotts treated Mr Powers over a long period of time, Poynter and Bishop (editors), op. cit., note 6 above.

${ }_{65}^{65}$ Morgagni, op. cit., note 19 above, vol. 3, p. 242.

${ }^{66}$ Van Swieten, op. cit., note 13 above, vol. 5, pp. 260-261.

${ }^{67}$ The best account of the development of an eighteenth-century medical career is R. Porter 'William Hunter: a surgeon and a gentleman', in W. F. Bynum and R. Porter (editors), William Hunter and the eighteenth-century medical world, Cambridge University Press, 1985, pp. 7-35. Hunter was, of course, an élite surgeon, but we have no reason to believe that the career pattern of physicians was fundamentally different, see W. F. Bynum, 'Physicians, hospitals and career structures in eighteenth-century London', in ibid., pp. 105-128.

${ }^{68}$ For an interesting exemplification of how medical time-tables are the product of dynamic interplay between the interests of patients and doctors, see J. A. Roth, Time-tables: structuring the passage of time in hospital treatment and other careers, New York, Bobbs-Merrill, 1963. 
THE RISE AND FALL OF THE METASTATIC THEORY

Historians have identified suasive and legitimating strategies within orthodox medicine in a wide variety of times and places. ${ }^{69}$ Following Jewson, we might conjecture that the precise nature of these strategies would change with the socio-economic basis of the dominant form of practice. Accordingly, suasive usages of the metastatic theory ought to be specific, at least to some considerable extent, to particular social circumstances and a particular period of time. The following section argues that this was indeed the case.

The idea that there is some relation between local and general disease is, of course, a very old one. ${ }^{70}$ There are several references in the Hippocratic Corpus to "metastatic affections ... . which travel from one to another part of the body". 71 The treatise Epidemics relates the case of a patient who suffered the transfer of gangrene from her arm to her lung. ${ }^{72}$ As Jarcho has noted, Galen warned that interrupting the flow of gouty matter to the joints might risk the creation of a more serious disease. ${ }^{73}$ Western physic thus received the full technical resources of the metastatic theory of pathogenesis as part of the legacy of Greek medicine. ${ }^{74}$

The notion that the movement of material from one site to another within the body was a prime source of danger was enthusiastically adopted by physicians in the medieval West. However, throughout the Middle Ages, metastatic conceptions of disease seem to have been employed in a manner systematically different from that characteristic of the seventeenth or eighteenth centuries. The possibility of metastasis was invoked not so much to legitimate the intervention of orthodox physics as to rationalize and emphasize the importance of a moderate, restrained, and cautious life-style for the maintenance of health ${ }^{75}$ This usage may be found, for example, in one of the most influential medical texts of the Middle Ages, the Regimen sanitatis Salernitanum, as the following quotation from Philemon Holland's English version illustrates:

\footnotetext{
${ }^{69}$ See, for example, T. M. Brown, 'The College of Physicians and the acceptance of iatromechanism in England', J. Hist. Biol., 1974, 7: 179-216; K. Figlio, 'Chlorosis and chronic disease in nineteenth-century Britain: the social constitution of somatic disease in a capitalist society', Social History, 1978, 3: 167-197; and note 4 above.

${ }^{70}$ See M. Solis-Cohen, 'Recognition through the centuries of the relationship between local and general diseases', Bull. Hist. Med., 1952, 26: 526-538.

${ }^{71}$ This aspect of Hippocratic and Galenic doctrine is discussed in some detail by R. E. Siegel, Galen's system of physiology and medicine, Basle, Karger, 1968, pp. 360-382. See also P. H. Niebyl, 'Venesection and the concept of the foreign body: a historical study in the therapeutic consequences of humoral and traumatic concepts of disease', PhD thesis, Yale University, 1969.

${ }_{72}$ E. Littré, Oeuvres complètes d'Hippocrate, Paris, Baillière, 1846, vol. 5, p. 181.

${ }_{73}^{73}$ Jarcho, op. cit., note 13 above.

${ }^{74}$ The question of whether or not the metastatic theory was ever put to suasive usage in classical times could only be definitively answered by a more accomplished classical scholar than the present author. However, my reasonably extensive reading of those classical texts available in translation and my perusal of secondary sources have revealed no examples.

${ }^{75}$ For a sensitive discussion of the medieval moral perspective on the maintenance of health, see O. Temkin, 'Medicine and the problem of moral responsibility', Bull. Hist. Med., 1949, 23: 1-20. For suggestions that the moral emphasis was itself a tactic of discourse, see J. Kroll and B. Bachrach, 'Sin and the etiology of disease in pre-crusade Europe', J. Hist. Med., 1986, 41: 395-415.
} 


\section{Nicolson}

... in the time of Ver or Spring, wee must eat little meat .... Red humours are increased and specially flegmatick, which (after the proportion of the season [winter]) then specially are ingendred ... and when Ver ... commeth those raw humours so gathered together, doe melt and spread through all the body: wherefore Nature is then greatly busie in digesting them. And therefore, in Ver season, if one eat much meat, it lesseth Nature to digest such flegmatick humours and causeth them to divert or turn another way: For by those humours, and great quantity of meat, Nature is oppressed. And so (thereby) such humours shall remain in the body undigested, and run to some member, and there breed some disease: and therefore we ought to take good heed, that we eat not any great quantity of meat in Ver. ${ }^{76}$

During the Renaissance, usage of the metastatic theory in a manner similar to that of Morgagni or Symcotts seems likewise to have been rare. If, for instance, one compares Morgagni's De sedibus with its nearest sixteenth-century equivalent-Antonio Benivieni's De abditis morborum causis - one finds that Benivieni was well aware of the possibility of the metastatic translation of disease. ${ }^{77}$ His text contains several clear accounts of the phenomenon. ${ }^{78}$ But, in Benivieni's hands, such ideas had no particular polemic or suasive function. This is not to say that Benivieni did not systematically distinguish between rash, unskilled, or ignorant practice and its opposite. All physicians of whatever era must make this distinction as a matter of course. But Benivieni, unlike Morgagni, did not employ the metastatic theory or indeed any other theoretical resource to exemplify or legitimate such discriminations. ${ }^{79}$

The present essay does not make the claim that any version of the metastatic theory was wholly peculiar to the seventeenth and eighteenth centuries. Perhaps further investigation might reveal medieval or Renaissance usages similar to those of Morgagni, Symcotts, and Van Sweiten. However, instances do not come readily to hand. In the seventeenth and eighteenth centuries, in contrast, the employment of the metastatic theory as a means of making polemical distinctions between good and bad medical practice was an especially prominent, characteristic, and regular feature of medical discourse.

${ }^{76}$ P. Holland, Regimen sanitatis Salerni: school of Salernes regiment [sic] of health, London, 1649, pp. 61-62.

${ }_{77}$ A. Benivieni, De abditis nonnullis ac mirandis morborum et sanationum causis, translated by Charles Singer, Springfield, Thomas, 1954.

${ }^{78}$ Ibid., pp. 121-122.

${ }^{79}$ Although economic and social rivalries between the various strata of the medical profession have been virtually a constant feature of European medicine, it seems likely that physicians in the sixteenth century and before were relatively more relaxed about alternative forms of practice and about the prerogatives of physic than they were to become in the seventeenth and eighteenth centuries. Benivieni, for instance, relates several examples of patients being successfully cured by empirics. He describes patients recovering through the neglect of physic, as a result of misunderstanding or wilfully disobeying their physicians' instructions, or even through drastic self-dosing after several physicians had failed and the case had been given up as hopeless. Such stories do not appear in the pages of De sedibus. Given that book's aggressive attitude towards self-treatment and unorthodox practice, not to mention its rigorous and comprehensive rationalism, it is unthinkable that any should.

For an interesting account of harmonious relations pertaining between the various medical strata, see K. Park, Doctors and medicine in early Renaissance Florence, Princeton University Press, 1985. For a contrasting picture, see P. Kibre, 'The Faculty of Medicine at Paris, charlatanism, and unlicensed medical practices in the later middle ages', Bull. Med. Hist., 1953, 27: 1-20. Garcia-Ballester makes the interesting point that in sixteenth-century Spain, relations between physicians and empirics were often very relaxed, the persecution of the Morisco empirics being sustained more by cultural and religious motives than by professional ones, L. Garcia-Ballester, 'Academism versus empiricism in practical medicine in sixteenth- 
What were the distinctive historical circumstances that led to an old idea increasing in popularity and being modified and utilized in new ways? The seventeenth and eighteenth centuries saw a great increase in the supply of professional medical attention. ${ }^{80}$ This process of medicalization was characterized by the expansion not only of orthodox physic but of all manner of unorthodox, fringe, and quack practice. Increasingly, ordinary practitioners of physic such as Symcotts were facing significant commercial challenge and rivalry. Furthermore, as Porter has recently argued, there is no evidence that the extent to which the populace employed self-treatment or domestic medicine declined sharply in this period. ${ }^{81}$ If anything, the evidence is that selfmedication actually increased. It may be conjectured, therefore, that, in the eighteenth century, arguments that could be used both against his professional rivals and against self-treatment would have had a particular attraction to the physician.

The rise of the metastatic theory was, no doubt, also aided by the fact that the leaders of eighteenth-century medical opinion, such as Sydenham, Morgagni, and Van Swieten, favoured materialist and naturalistic conceptions of pathology-as, apparently, did down-to-earth practical men such as Symcotts. The metastatic theory accorded the cause and the cure of disease a natural and material basis. Its usage was perhaps also encouraged by increased emphasis on morbid particles, rather than or as well as corrupted humours, as the putative agencies of disease ${ }^{82}$ However, the theory did have one important feature in common with earlier views on pathogenesis. It retained a strong moral dimension. The roots of ill health still lay in the way one conducted one's life. Protection against disease was achievable by obeying the rules of therapy and life-style as revealed by physic.

A quite specific set of social and intellectual circumstances allowed the metastatic theory to flourish in the eighteenth century. First, physicians felt seriously threatened by competition from other varieties of medical practitioners and sought polemic resources that would be of help to them in this competitive struggle. Second, the metastatic theory of pathogenesis readily harmonized with the contemporary rational framework of medicine. Third, the physician's authority and social status, while chronically problematic, were sufficiently secure and elevated for him to feel able to criticize the conduct of his client group. ${ }^{83}$

century Spain with regard to Morisco practioners', in A. Wear, R. K. French, and I. M. Lonie (editors), The medical Renaissance of the sixteenth century, Cambridge University Press, 1985, pp. 246-270.

${ }^{80}$ This question is extensively discussed in R. Porter, 'The patient in the eighteenth century' in A. Wear (editor), The history of medicine in society, Cambridge University Press, [forthcoming]. See also I. Loudon, " "The vile race of quacks with which this country is infested"', in W. F. Bynum and R. Porter (editors), Medical fringe and medical orthodoxy 1750-1850, London, Croom Helm, 1987, pp. 106-128.

81 Ibid.

${ }^{82}$ See K. D. Keele, 'The Sydenham-Boyle theory of morbific particles', Med. Hist. 1974, 18: 240-248. Morgagni employed both humoural and particulate explanations of metastasis. Particulate explanations, however, seem to predominate both in De sedibus and in Van Swieten's Commentaries.

${ }_{83}$ It is possible that the relatively lowly position of many Greek physicians (see note 91 below) is one explanation for their failure to exploit the suasive potential of the metastatic theory. Temkin, op. cit., note 75 above, has pointed out that it is unlikely that Greek or Roman patricians would allow their social inferiors to meddle with "whatever conscience they possessed". It seems equally unlikely that the physicians of classical times often harangued their patients with threats and promises of ill health if they did not submit to the authority of physic - at least not in the robust and direct manner the eighteenth-century physician, who was nearly the social equal of his patients, felt able to adopt. But cf. Galen XVII B 145-6 K. 


\section{Nicolson}

In the nineteenth century, the status of medicine and the authority of the doctor might still be problematic but the medical profession began to adopt corporate, rather than individual, strategies in their defence. Medical practitioners successfully organized themselves to achieve full professionalization and a legal monopoly. The hegemony and authority of physic was no longer so crucially dependent upon the outcome of direct social interaction between physician and patient. ${ }^{84}$ Meanwhile, hospital medicine became the dominant means of production of medical knowledge and medicine became self-consciously scientific as never before.

Under these changed circumstances, the metastatic theory rapidly fell into desuetude. Evidence of its decline is provided by changes in the treatment of leg ulcer. Irvine Loudon has carefully charted how the notion that the rapid healing of leg ulcers could produce adverse internal symptoms quickly went out of fashion in the late eighteenth- and early nineteenth centuries. ${ }^{85}$ The aim of therapy became the immediate closure of the ulcer. Initially, Loudon suggests, the new treatment arose as a consequence of improvements in the status and confidence of the surgeon. It was subsequently supported by changes in the dominant conception of pathology. ${ }^{86} \mathrm{~A}$ local lesion became simply that; no longer was it a particular expression of pathogical processes that affected the whole body.

Claude Bernard, in his manifesto for the new age of experimental medicine, acclaimed the demise of the old idea of metastatis as one of the major successes of medical science: "Now that the cause of the itch is known and experimentally determined, it has all become scientific, and empiricism has disappeared. We know the tick, and by it we explain the transmission of the itch, the skin changes and the cure .... No further hypotheses need now be made about the metastasis of the itch . ... Here is a disease that has reached the experimental stage; and physicians are masters of it just as much as physicists and chemists are masters of a phenomenon of mineral nature."87 Thus the metastatic theory of scabies, which occupied so much space in Morgagni's great eighteenth-century text, had reached the end of its career. The metastatic theory was now merely a symbol of how the old order had been surpassed and a new age of scientific medicine ushered in.

Meanwhile, Récamier had given the term "metastasis" what was to become its new and modern meaning by using it to refer to the secondary spread of cancer tumours. ${ }^{88}$ The distance between the eighteenth- and the nineteenth-century ideas of metastasis is

\footnotetext{
${ }^{84}$ The enormous changes that came across medicine in the early-nineteenth century have been discussed by many authors. The accounts most relevant to our present concerns are probably Reiser, op. cit., note 2 above; Jewson, op. cit., note 1 above; and Foucault, op. cit., note 9 above. See also W. R. Arney and B. J. Bergen, Medicine and the management of living, University of Chicago Press, 1985; G. Welty, 'The emergence of the modern mode of medical production', Humanity and Society, 1985, 9: 371-387; and Armstrong, op. cit., note 9 above.

${ }^{85}$ I. Loudon, 'Leg ulcers in the eighteenth and early nineteenth centuries', J. R. Coll. Gen. Practnrs, 1981, 31: 263-273; and idem., 'Leg ulcers in the eighteenth and early nineteenth centuries, II. Treatment', ibid., 1982, 32: 301-309.

${ }^{86}$ The rise in the status of the surgeon and changes in the dominant conception of pathology are not unconnected, see O. Temkin, 'The role of surgery in the rise of modern medical thought', Bull. Hist. Med., 1951, 25: 255-259.

${ }^{87} \mathrm{C}$. Bernard, An introduction to the study of experimental medicine, trans. H. C. Greene, New York, Schuman, 1949, pp. 214-215.

${ }^{88}$ J. C. A. Récamier, Recherches sur le traitment du cancer, Paris, Gabon, 1829.
} 
well-illustrated by the change in the connotations that surround the term. As we have seen, to Van Swieten the cause of cancers often lay in one's own conduct. Tumours developed from inflammations as the consequence of a failure to submit oneself to the authority of physic. Cancer was part of the agenda of the secular morality of health. This moral perspective on the disease is absent from the nineteenth-century conception of cancer or of metastasis. As Virchow wrote: "There is just no purpose to be discovered in somebody's developing a tumour. This is, as we use to say, an accident, an aimless event by which in the animal body the orderly course of a series of phenomena is stimulated, the visible result of which is the tumour. Pathogenesis, therefore, can have no other task but to acquaint itself with that accident and to explore the laws according to which the subsequent phenomena take their course." 89 The social significance of pathogenesis had changed between the eighteenth and the nineteenth centuries. Under new cognitive and social circumstances, the metastatic theory was no longer useful as an instrument of suasion and legitimation.

Eighteenth-century medical knowledge has long presented a serious problem to historians of medicine. For one thing, it is extremely complicated. For another, it is very different from the medical knowledge of the nineteenth and twentieth centuries. There is a limit to the extent it can be explained in terms of its positive content as judged by twentieth-century standards. The customary historiographical practice has, therefore, been to interpret eighteenth-century medical theory in terms of the inputs it received, from the classical tradition, from scientific investigation, and from contemporary philosophy. ${ }^{90}$ Historians have also considered the extent to which it was consistent and rational in its own terms. ${ }^{91}$

Investigations along these lines have, undoubtedly, added much to our understanding of eighteenth-century medicine. However, it is obvious that the explanation of medical knowledge that they provide is incomplete. Further questions are inevitably begged. Why did eighteenth-century medical men, either collectively or individually, choose to incorporate certain philosophical tenets into their medical discourse and not others? Why were certain elements of the classical tradition adopted and developed and others discarded? Noting the availability of cultural or technical resources has little explanatory power in itself. It merely sets the scene within which the creative process of the production and utilization of knowledge takes place. Neither are rationality and consistency adequate historical explanations for held belief, since the number of rationally consistent forms of discourse is potentially infinite. Why was one particular form chosen or constructed, at any particular time and place? Even with the current widespread acceptance of the deficiencies of intellectual historiography, it seems that, in some areas at least, our understanding of the cognitive content of eighteenth-century medicine has not yet caught up with the improvement in our knowledge of its social context.

\footnotetext{
${ }^{89}$ Quoted and translated by Temkin, op. cit., note 75 above.

${ }^{90}$ For a good and socially sensitive example of this genre, see C. Lawrence 'Medicine as culture: Edinburgh and the Scottish Enlightenment', PhD thesis, University of London, 1984.

${ }^{91}$ For a contextualized version of this genre, see F. Duchesneau 'Vitalism in late eighteenth-century physiology: the cases of Barthez, Blumenbach and John Hunter', in Bynum and Porter (editors), op. cit., note 68 above, pp. 259-295.
} 


\section{Nicolson}

But examples of more fully explanatory historiography are readily available. Ludwig Edelstein's analysis of Hippocratic medicine provides one of the earliest and finest examples of an approach that seeks to provide a more complete explanation of the medical knowledge of the past. ${ }^{92}$ The Hippocratic Corpus contains many examples of fine observation at the bedside. Prognosis was, by our own standards, quite technically accomplished. These features of the Corpus have often been explained in terms of the Greek physician sharing modern clinical and scientific concerns. Edelstein, however, pointed out that the social status of the Hippocratic physician was the relatively low one of a craftsman. The physician gained, like most Greek craftsmen, an insecure livelihood, often having to travel from town to town in search of customers. As a consequence, he needed to gain the confidence of prospective customers quickly in order to secure their patronage. He also needed to be able accurately to differentiate between curable and incurable disorders. Failing to cure patients would quickly harm his reputation. Edelstein, thus, explained the Hippocratic physician's concern with prognosis, not in terms of an adumbration of the modern clinical attitude, but in terms of a business requirement. Being able to foretell the course of disease was commercially advantageous.

Edelstein, it will be noted, did not explain medical knowledge wholly in terms of cultural input but principally in terms of its context of use. He gave full importance to the active agency of historical figures, who devised and utilized knowledge to serve particular purposes at particular times and places. Edelstein thus shed light on the actual production of medical knowledge by demonstrating how practitioners developed forms of knowledge which helped them in the pursuit of specific professional goals.

Jewson has laid the foundations for a similar explanation of eighteenth-century medical knowledge. In the present paper, I have drawn upon Jewson's analysis to show that even in the explanation of apparently quite technical aspects of medical theory a central, constitutive role must often be accorded to physicians' social and material interests. ${ }^{93}$ The metastatic theory served the business interests of the eighteenthcentury physician in the same way as a developed concern with prognosis served the business interests of the Hippocratic physician.

A historiographic emphasis upon the professional interests of the medical profession also finds common ground with the current interest in writing history of medicine from

\footnotetext{
92 L. Edelstein, 'The Hippocratic physician', in O. Temkin and C. L. Temkin (editors), Ancient medicine: selected papers of Ludwig Edelstein, Baltimore, Md., Johns Hopkins Press, 1967, pp. 87-110. This paper was originally published in German in 1931. See also O. Temkin, 'Greek medicine as science and craft', Isis, 1953, 44: 213-225; and V. Nutton 'Murders and miracles: lay attitudes towards medicine in classical antiquity', in Porter (editor), op. cit., note 3 above, pp. 23-53.

${ }^{93} \mathrm{My}$ discussion of interests is based upon the theoretical work of sociologists of knowledge, see B. Barnes, Scientific knowledge and sociological theory, London, Routledge \& Kegan Paul, 1974; D. Bloor, Knowledge and social imagery, London, Routledge \& Kegan Paul, 1976; B. Barnes and D. MacKenzie, 'On the role of interests in scientific change', in R. Wallis (editor), On the margins of sciences: the social construction of rejected knowledge, Keele, Sociological Review Monographs, 1979, vol. 27, pp. 49-66. For empirical exemplifications, see D. MacKenzie, Statistics in Britain, 1865-1930: the social construction of scientific knowledge, Edinburgh University Press, 1981; A. Pickering, 'The role of interests in high-energy physics: the choice between charm and colour', in K. D. Knorr, R. Krohn, and R. Whitley (editors) The social process of scientific investigation, Dordrecht, Reidel, 1980, pp. 107-138.
} 
the patient's point of view-doing medical history from below, as Roy Porter has recently put it. ${ }^{94}$ The chief professional interest of medical practitioners is obvious. It is an adequate supply of patients. In the eighteenth century as in pre-Socratic Greece, the doctor must address the patient directly in order to create and maintain a demand for his services. Medical knowledge is formed, therefore, within the dynamic interplay between the interests of sufferers and the interests of practitioners. In the eighteenth century, as the example of the metastatic theory evidences, it is in the encounter between doctor and client that we see the use to which medical knowledge is put, the purpose for which it has been devised. ${ }^{95}$

It also seems reasonable to make the further suggestion that, if the professional tactics of healers are to be fully understood, we must develop a wholeheartedly anthropological perspective on ideas of health and disease. ${ }^{96}$ Mary Douglas set out the four great verbal weapons of social control as being time, money, God, and nature. ${ }^{97} \mathrm{We}$ might, on the basis of the discourse studied above, add pain and death to the list. But, of course, none of these rhetorical constraints - or doom points, as Douglas termed them - has any power in itself. As Douglas has also pointed out, risk is a collective construct. ${ }^{98} \mathrm{~A}$ witch-doctor would be impotent to mobilize concern about supernatural pathogenesis in a wholly secular and materialist society. Likewise, a physician arguing that danger will result if morbid matter is transferred from one bodily site to another would not be heeded, save in a society that already gives credence to the possibility of disease being caused by the accumulation of injurious matter within the body. Doctors have been called anxietymakers. ${ }^{99}$ They might more reasonably be seen as expressing and utilizing, as well as, of course, alleviating, anxieties already present in their culture. No one could wield the doom-point arguments credibly if their premises were not collectively endorsed. Thus it must be admitted that the present essay does not fully elucidate the role played by the metastatic theory in discourse about health and disease. To understand what made the metastatic doom-points credible, we must turn from studying the discourse of practitioners to the community of sufferers. Why for so long were so many people in Western Europe concerned with the dangers of internal pollution from morbid

\footnotetext{
${ }^{94}$ R. Porter, 'The patient's view: doing medical history from below', Theory and Society, 1985, 14: $175-198$.

${ }^{95}$ For a similarly socio-economic perspective on popular medical knowledge in the eighteenth century, see W. Coleman, 'Health and hygiene in the Encyclopédie: a medical doctrine for the bourgeoisie', J. Hist. Med., 1974, 24: 399-421. For accounts of how the wider social and economic interests of medical practitioner, that is interest outside the immediate sphere of patient-practitioner interaction, conditioned medical theory, see C. Lawrence, 'The nervous system and society in the Scottish Enlightenment', in B. Barnes and S. Shapin (editors), Natural order: historical studies of scientific culture, Beverly Hills, Calif., and London, Sage, 1979, pp. 19-40; and T. Brown 'From mechanism to vitalism in eighteenth-century English physiology', J. Hist. Biol., 1974, 7: 179-216.

${ }^{96}$ For a review of anthropological-inspired work in recent historiography of medicine, see M. MacDonald, 'Anthropological perspectives in the history of science and medicine', in P. Corsi and P. Weindling (editors), Information sources in the history of science and medicine, London, Butterworth, 1983, pp. 61-80.

${ }^{97}$ M. Douglas, 'Environments at risk', in idem, Implicit meanings: essays in anthropology, London, Routledge \& Kegan Paul, 1975, pp. 230-248.

${ }_{98}$ M. Douglas and A. Wildavsky, Risk and culture, Berkeley, University of California Press, 1982.

99 Comfort, op. cit., note 4 above.
} 


\section{Nicolson}

matter? ${ }^{100}$ Alternative explanations for disease were always actually or potentially available. ${ }^{101}$ Only when further investigation has elucidated this question shall we fully understand why the eighteenth-century physician found it worthwhile to employ the metastatic theory of pathogenesis as a tool of professional interest and social control.

\section{ACKNOWLEDGEMENTS}

Mike Barfoot, Sandra Cavallo, Mary Fissell, Roy Porter, Virginia Smith, and Professor G. E. R. Lloyd were all kind enough to comment on earlier drafts of this paper. It has been much modified in the light of what they had to say and it is a pleasure to thank them. Any remaining factual errors or untenable speculations are entirely my responsibility. Throughout the period of preparation of this paper, I have been supported by the Wellcome Trust, to whom I wish to record my gratitude.

${ }^{100}$ Very suggestive remarks about pollution beliefs are to be found in M. Douglas, Purity and danger, London, Routledge \& Kegan Paul, 1966; and idem, Cultural bias, London, Royal Anthropological Institute, 1978.

${ }^{101}$ See O. Temkin 'Health and disease', in P. P. Weiner (editor), Dictionary of the history of ideas, New York, Charles Scribner's Sons, 1973, 4 vols., vol. 2, 395-407; and various essays on theories of disease and healing in D. Landy (editor), Culture, disease and healing: studies in medical anthropology, London, Macmillan, 1977. 